First Peoples Child \& Family Review

A Journal on Innovation and Best Practices in Aboriginal Child Welfare Administration,

Research, Policy \& Practice

\title{
Metaphorical Reflections on the Colonial Circus of the Drunken Indian and the Kidney Machine
}

\section{Steven Koptie and Cynthia Wesley-Esquimaux}

Volume 4, Number 1, 2009

URI: https://id.erudit.org/iderudit/1069351ar

DOI: https://doi.org/10.7202/1069351ar

See table of contents

Publisher(s)

First Nations Child and Family Caring Society of Canada

\section{ISSN}

1708-489X (print)

2293-6610 (digital)

Explore this journal

Cite this article

Koptie, S. \& Wesley-Esquimaux, C. (2009). Metaphorical Reflections on the Colonial Circus of the Drunken Indian and the Kidney Machine. First Peoples Child \& Family Review, 4(1), 66-79. https://doi.org/10.7202/1069351ar

\section{Article abstract}

This paper represents the need for First Nations community workers to share their narratives of experience and wisdom for academic review. A growing number of mature Indigenous social service workers are returning to Canada's learning centers where they are articulating observations and insights to Indigenous experience in colonial Canada. It is imperative that post-colonial academic literature include these contributions. True reconciliation between Canada and First Peoples is only possible if those stories of resilience are reflected back from the experience of historic trauma and unresolved intergenerational suffering.
This document is protected by copyright law. Use of the services of Érudit (including reproduction) is subject to its terms and conditions, which can be viewed online.

https://apropos.erudit.org/en/users/policy-on-use/ 


\title{
Metaphorical Reflections on the Colonial Circus of the Drunken Indian and the Kidney Machine
}

\author{
Steven Koptie ${ }^{a}$ with Editorial Assistance by Cynthia Wesley-Esquimaux ${ }^{b}$
}

${ }^{\text {a }}$ MA Student, University of Toronto, Toronto, Ontario, Canada.

${ }^{\mathrm{b}}$ Assistant Professor, Jointly appointed to the Department of Aboriginal Studies and the Faculty of Social Work, University of Toronto, Toronto, Ontario, Canada,

\begin{abstract}
This paper represents the need for First Nations community workers to share their narratives of experience and wisdom for academic review. A growing number of mature Indigenous social service workers are returning to Canada's learning centers where they are articulating observations and insights to Indigenous experience in colonial Canada. It is imperative that post-colonial academic literature include these contributions. True reconciliation between Canada and First Peoples is only possible if those stories of resilience are reflected back from the experience of historic trauma and unresolved intergenerational suffering.
\end{abstract}

an unrelenting expression and fixation on pathology. I use the terms Indigenous peoples, First Nations people or First Peoples throughout this paper because the term Aboriginal is a political definition created by agents of oppression that have equally confounded the socio-historical realities of an entire Indigenous population. The word Indian is used to remind myself of what it feels like to have your identity reduced to a carnival sideshow oddity or circus freak. Modern sensitivities still allow, push and tolerate iconic mascots and other images that devalue the term "Indians" as a designator for a diverse and complex range of cultures, languages and life experiences.

Clifford Geertz (2000), in his collection of essays titled Available Light reflected on the importance of promoting discourse theory in cultural psychology. How stories are expressed draws on the cumulative knowledge of language, art, literature, history, law, philosophy and what he calls an "inconstant science", anthropology. He writes;

"It has been the convention of most schools to treat the art of narrative-song, drama, fiction, theater whatever-as more "decoration" than necessity, as something with which to grace leisure, sometimes even as something morally exemplary. Despite that, we frame the accounts of our cultural origins and our most cherished 


\section{Acknowledgement}

The author is eternally grateful to Indigenous scholars such as Dr. Cynthia Wesley-Esquimaux, Dr. Suzanne Stewart, Dr. John-Paul Restoule, Lee Maracle (Honorary PhD long overdue) and Marlyn Bennett (PhD in progress) for providing a culturally safe space to write and reflect on sometimes lonely journeys of recovery. Indigenous thinkers and scholars play vital roles as path-finders and mentors to navigating the rigors of academia. Academic spaces remain foreign, perplexing and not necessarily ready for some of the stories coming in from "Indian country." The metaphoric carnival or circus of colonization that is offered in this paper will hopefully provide a framework for contextualizing long-standing misunderstood and mislabeled 'pathologies' such as uncivilized drunken Indians. Notions that confound and defy Indigenous cultural rationalizations but continue to inform a colonizer's view of "who" Aboriginal peoples apparently are.

beliefs in story form, and it is not just the "content" of these stories that grip us, but their narrative artifice. Our immediate experience, what happened, yesterday or the day before is framed in the same storied way. Even more striking, we represent our lives (to ourselves as well as to others) in the form of narrative. It is not surprising that psychoanalysts now recognize that personhood implicates narrative "neurosis" being a reflection of either an insufficient, incomplete, or inappropriate story about oneself. Recall that Peter Pan asks Wendy to return to Never Never Land with him, he gives as his reason that she could teach the Lost Boys there how to tell stories. If they knew how to tell them, the Lost Boys might be able to grow up. (p.193)"

Therefore, perhaps the biggest challenge and burden for First Nations Peoples and their healers is to restore story-telling and promote the sharing of stories of cultural genocide and resilience in the realm of socio-historic victimization (Duran, 1995). This paper is a narrative collage made from fragments of experiences and observations of an Indigenous man raised on a travelling carnival, or the outdoor amusement industry, today a more politically correct euphemism. One day I hope to write a book titled "Running the Alibi: Observations and Recollections of a Half Breed, Carny Bum" to weave together narratives that draw parallels between the carnival or circus life and Canada's absurd domination of First Nations. A thirty year social work, mental health, addictions counselor, land claim researcher and program design career in urban and remote First Nations community's offers useful insights to the never ending stories or "jackpots" told by lost boys. Running the alibi is the 'wise guy' way of gaining advantage over "marks", a carnival's apprehensive customers. Creative, confusing and colorful language manipulations hide predatory intentions and hungry realities. This paper is wrapped around metaphoric frameworks that mask gangster conduct which victimizes vulnerable folks. The parallels between carnival victims and Native people rest in the historic narrative of alcohol abuse and the unresolved historic trauma that continues to mark Indigenous people for perverse vulnerability. Colonization fits this distortion or alibi for greed because it shelters worst intentions and shields bureaucratic bandits from accusations of criminality and as perpetrators of chaos, including genocide, of Indigenous peoples.

Raphael Lemkin, a Polish Jew, led the development of a universal definition for the word "genocide" and spearheaded the passage of the United Nations first human rights treaty. Samantha Power (2000), in her book, A Problem from Hell, America and the Age of Genocide, tells the story of the fifteen year effort by Lemkin to make human rights an integral part of the United Nations. She also recounts the efforts of America and Britain to weaken Lemkin's work. In addition, Canada and Russia in the early years of the 21 st century remain obstacles in a twenty year project at the United Nations to entrench human rights for Indigenous people around the world. Lemkin often used what he called "a constant prodding" to forever prevent another Hitler by noting that the "legislators imagination must be superior to the criminal" (Power, 2002:57). The General Assembly of the United Nations settled on December 9, 1948 on a definition of genocide as;
Any of the following acts committed with intent to destroy, in whole or in part, a national, ethnical, racial, or religious group, as such: killing members of the group; causing serious bodily or mental harm to members of the group; deliberately inflicting on the group conditions of life calculated to bring about it physical destruction in whole or in part; imposing measures intended to prevent births within the group; forcibly transferring children of the group to another group (Power, 2002:57).

The history of colonization must begin by fully integrating the stories of genocidal experiences from the past seven generations in order to properly understand and fully comprehend First Peoples experience on this continent. First Peoples scholars are reviewing the anger and unresolved grief that is closely associated with sustained intergenerational trauma in order to make sense of the outcome of multiple losses and the subsequent marginalization of an entire people (YellowhorseBraveheart, 2004, Wesley-Esquimaux, 2004). This has been necessary to facilitate the re-civilization of Turtle Island (North America) and the enlivening of an almost completely silenced world-view. For the past fifty years, 
the majority of First Peoples healers' time has been focused on reviving victims of trauma from what we now recognize as an historical, cultural and spiritual genocide.

Having worked in areas of mental health, child welfare, justice, violence, addictions and youth with Fetal Alcohol Spectrum Disorder (FASD), I have long wondered how we can create healing environments where one is safe to tell their stories and organize their experience in the face of long standing trauma. The richness of generations of stories that once maintained social cohesion have long been devastated and replaced by a state of cultural shock. This shock follows unrelenting trauma from warfare, dispossession, poverty, disease, oppression and forced assimilation. Healing in First Peoples communities will take a massive transformation from "victimization" to "survivorship" to "victorization" (Wesley-Esquimaux, 2007) and the guiding of individuals through traumas that cannot be solely represented as individual fault. First Peoples need to acquire a comprehensive understanding that they did not deserve to be hurt and that telling their story will not lead to their being regarded as crazy. Equally powerful for First Peoples healing will be a realization that the historical upheavals and injustices that led to internalized self-hatred, and ultimately became interwoven in many generations of First Peoples families, was an almost exclusively external onslaught (Duran, 2006). Although, initially, cultural imperatives across First Nations did not promote active resistance to external social/political upheavals, because guests were welcomed, nor was it seen as necessary to fight to maintain rights in the face of "others" with more power, because it was a given by Indigenous peoples that rights were sacred. Faith in Treaties premised on reciprocity by Indigenous peoples, turned into alibis for greed for colonial powers. Land purchases came to represent conquest and domination. Today's generation of Indigenous scholars and healers bring unique perspectives to the reconciliation of historic trauma from Residential Schools, the 60's Scoop, and the continuing impacts of colonial institutions such as Corrections Canada jails. The justice system sustains what can be referred to as Canada's largest reserve, which contributes, as well as masks, an increasingly frightening legacy of problem drinking patterns, health and social issues, and growing unresolved mental health complications of those atrocities. Is homelessness in our homelands part of our 'homelandlessness' and a measure of the loss of family and community connection? Has the loss of positive Indigenous identities relegated First Peoples to sad representatives of museum-based cultures only to be paraded at opening ceremonies of Olympics or iconic images on banknotes? The broad spectrum between the drunken Indian and the noble savage remains unfathomable, especially for Indigenous children, who remain our most powerless and helpless victims of cultural, social and spiritual upheaval.
The tragic loss of two babies on the Yellow Quill Reserve (2009) in Saskatchewan last winter added to the roster of stories that painfully remind us of the kind of all too frequently occurring events which cause community helpers to despair. A drunken Indian dropped two toddlers in -50c without any proper protective clothing or shelter and their lifeless remains were found too many hours later, lost to traumatic degradation. The painful loss and suffering of innocent children continues to be a real and unrelenting tragedy for far too many First Peoples and their communities. Indigenous scholars must intercede in instances where holistic community wellness issues beg to be loudly addressed rather than allowed to fall into a silence that prevents scrutiny of our collective natural responsibilities to future generations. This scrutiny is paramount as restorative justice is being contemplated at Yellow Quill. This move challenges all First Peoples to break the silence that allows hurt people to hurt other people, especially when they are our children. Why does the silence in our communities only get broken through the lament of mothers, grandmothers, sisters, brothers and yes fathers too, when we face the loss of innocent lives to preventable atrocities like suicide and murder? As a parent, my feelings of despair lay in knowing that when we neglect, fail to protect, and ultimately abandon our children to the cruelest aspects of life, we are in fact, complicit in killing them. I recently returned from community work in northwestern Ontario as a community mental health worker where I dealt with every possible social issue that can bubble forth from a failure to provide basic safety to all young people, and I feel very much a personal failure for not being able the make a discernable difference in such extreme circumstances. Are we as a people willing to address the need to create a re-parenting process for our children in order to restore the very basic human concepts of what families are supposed to offer? We as First Peoples in Canada are facing an uncertain future because we are forgetting the needs of future generations in too many places. Our thoughtlessness is evident when drunkenness replaces the protection of our most precious gift from Creation.

In the north, and in southern Ontario, I ran violence prevention workshops called the "Children are Watching" in an effort to teach our people how to re-establish safe environments. Successive generations of children have become physically, socially emotionally and spiritually lost during their living experiences, and many have died, sometimes because of adults being unable to assume their traditional roles of preparing our youth for humane and positive citizenship. After reading about the Yellow Quill tragedy I see a need to prepare new workshops on "Who is Watching Our Children?" This "challenge to protect our children" must be spoken out loud, the silence broken, as a part of our own struggle against historic impacts. We must 
admit to each other that our survival as a healthy and strong people requires that we do whatever we can to protect the lives of our children, all of them, everywhere. Wars are fought over less.

Working with FASD youth in Hamilton, Ontario involved teaching youth to know one story for each of the Seven Grandfather Teachings: Wisdom, Love, Respect, Honesty, Bravery, Humility and Truth. These values were given as guides to wise problem solving and decision-making (Koptie, 2004). These teachings, given from a strengths model perspective, allowed us to encourage FASD young people to avoid impulsive behaviors that were problematic and dangerous. The need for safe external oversight or an external brain support (therapist, counselor, house matron) is not fully appreciated in environments unprepared for the massive special needs of neurologically damaged youth. This is possibly the most important narrative that we have failed to share and in the end the suffering of young people becomes inexcusable when we consider the huge revenues from the marketing and sale of the teratogen, alcohol. Mate (2007) describes Bruce Alexander's concept that any susceptible organism under stress with access to a drug with addictive potential is vulnerable to addiction in their struggle to relieve physical, psychological, spiritual and social environmental pain. This is not a race issue as all races are impacted by alcohol abuse.

The narrative missing from the Yellow Quill experience is a long overdue and honest dialogue on the reality of FASD/ARND. Fetal Alcohol Spectrum Disorder and Alcohol Related Neurological Disorders (FASD/ ARND) must be the Creator's most poignant challenge to First Nations people to re-examine and re-introduce responsible sobriety right across Canada. The loss of successive generations of hope on the ground in our First Nation's suggests a "massive drunken metaphor of excess" which causes me to fear a continuing and unrelenting destruction in specific segments of our societies, our youth. My research goals encompass the following questions; is it possible to reverse the loss of hope for many families that FASD represents? Can we reverse our collective failure to act to preserve and advance a healthy childhood and the coming of age of our youth? Will our children, subjected to teratogens (agents of birth defects) in the womb, be able to assume a role in the restoration of home and community that we seek in the healing process? Are youth repeating pathological cycles of self-destructive and self-defeating behaviors because of gestational brain damage? What about the young father in Yellow Quill, has anybody asked the obvious questions? Where will the carnival be set-up next? Will the continued abusive consumption of alcohol mean a continuity of decline rather than a return towards our natural sovereignty? (Mohawk Girls, 2005). These questions have global implications when the precious gifts the Creator has offered are being mistreated and neglected. There are many perspectives that First Peoples scholars may want to review in order to articulate and orientate our experience and build a way forward in the face of tragic "on the ground crises" that paralyze many First Nations communities. They also confirm many of the traps of "Systemantics" that John Gall (1975) and Alfred Korzybski (1933) claim lead to never ending patterns of catastrophe.

Making sense out of nonsense is the most important service provided by gifted Native helpers. Our marvelous humor suggests a legacy of resilience in enduring trials and tribulations that accentuates the ironies of our circumstance. Those immersed in bringing health alternatives to First Peoples rarely get the recognition they deserve or any real understanding from Euro-centric experts. This paradox has led me back to the words of John Gall (1975) whose field of interest, Systemantics, the study of organizational behavior, became the main focus of my studies at University of Windsor in the 1970's. Gall sought to explain "how systems work and especially how they fail," and he demonstrated how a lot of things do not work well and in fact never did. As a returning graduate student, I want to return to some of these ideas so that I can use those theories to reflect on 30 trying years of mostly failure to shift social work "best practices" to "wise practices" (CAAN, 2004) on behalf of First Peoples. This has been daunted by a dominant social system more inclined to maintain racial supremacy, than restore human dignity. The big lie, that civilization is good for us (Trudell, 2004), is held up, but what really happens is that instead, a systemic attack on First Peoples is undertaken, the most recent that by Widdowson and Howard (2009), and this is very much representative of the failure John Gall wanted to present as silly collective ignorance;

\section{Charles Darwin made it a rule to write down immediately any observation or argument that seemed to run counter to his theories. He had noticed that we humans tend to forget inconvenient facts, and if special notice is not taken of them, they simply fade out of awareness. (Gall, 1986:xx)}

Inconvenient facts or truths are not limited to the language of denial that Al Gore (2006) attributes to climate change. He cites political, economical, and social inaction as significant contributors. Gall (1986) suggests that there are cascades of failures or sequential events by which a system fails, each following a failure to contain the initial mistake. The Indian Act surely represents systemic institutional approaches to assimilate or integrate First Peoples into the dominant culture, whatever that integration may represent within the Canadian consciousness. He claims an awkward metaphor can be used to distinguish a system that can be turned on but cannot be turned off. He would have termed such systemic entities as the Indian Act, a Frankensteinian Monster. 


\section{Metaphorical Reflections on the Colonial Circus of the Drunken Indian and the Kidney Machine}

Gall's ideas reflect a profound logic which describes the paradox of invented bureaucracies such Indian and Northern Affairs Canada (INAC) where those administering this system become so narrow and specialized that they lose connection with an outside reality. Insular directives from deep within this hierarchal structure almost assure that the system itself cannot do what it says it is doing. Real world experience is excluded from what is reported up and down the system; resulting in the big lie (Trudell 2004). This is how it becomes a Frankensteinian Monster that ultimately disintegrates into "systemantic" chaos, with the inherently tragic consequences that ultimately follow. First Peoples today live within what Lee Maracle (2009) has termed "plunder zones." The failure of removal and assimilation outlined by Indian Act policy has justified unmitigated access to Indian lands and resources. The fact is we are enmeshed in a Victorian era strategy in the 21st century for governing the territory now called Canada. The Dominion of Canada is still dependent on concepts like reserves and Indian status, but this dependency can no longer hide racebased rationalizations for colonization and Euro-centric white supremacy.

Gall's work can be utilized to move beyond futile debates on making a monster system work. His work comes from his study of Alfred Korzybski (1933) and his work in general semantics. The work of these scholars furthers my desire to reframe our collective experience as First Peoples and speaks to the need to articulate that historic experience in our own words and stories. Disharmony is human relationships is due to limited thinking and misconceived abstractions. Albert Ellis (1975) the father of rational emotive and cognitive behavioral healing gives an appropriate example that could address other crazy misconceptions, lazy Indians and Indian time, and can even be regarded as a good rendition of running the alibi:

In his famous book Science and Sanity, Korzybski lambastes the "'is' of identity," claiming that when we state "A is lazy" this means something quite different from the descriptive statement "A does not get up in the morning" or "A refuses to get up in the morning." For the statement "A is lazy" can mean many things and may represent many different orders of abstraction. It may mean for example, "A sometimes does not get up in the morning," "A rarely gets up in the morning," "A gets up early in the morning but procrastinates about taking a shower," "A deliberately gets up late in the morning," " $A$ tries hard to get up early in the morning but against his will falls asleep again," and so on. The statement " $A$ is lazy" seems to mean $A$ always, under all conditions, does things late or never. But does it? Usually, of course, it doesn't. But we continually employ such omnibussounding statements. Wrongly! (pg. vii)
Liberation from domination according to Lee Maracle (2009) will come from implementing creative plans against ridiculous abstractions that maintain oppression, racism, sexism and colonization developed from within our traditional wisdom and knowledge that are carried in our stories of survival and renewal.

Korzybski's work, Science and Sanity (1933), contains his famous axiom "the map is not the territory". This axiom was his challenge to those who misuse language and communication and attach foolish meaning and descriptions to ideologies requiring abstract levels of thought. That we accept normative representations as factual has devastating consequences for our well being as people. The drunken Indian is a sad stereotype that is widely accepted as the representation and perceived identity for a whole race. It is an icon locked in the collective consciousness of the dominant culture that misrepresents the real evils of the existential space between the present and historical experience of all humanity. This creation of inferiority through social pathology maintains a language of the "other or outsider" that is used to legitimize racial supremacy. How can we feel sorry for drunken people whose existence is dependent on the evils of alcohol? One of the 20th century leaders of civil rights, who fought for transformative change that allows for President Barak Obama, the Reverend Martin Luther King Jr. (1963) referred to these evils in his own writing in regards to America:

Our nation was born in genocide when it
embraced the doctrine that the original
American, the Indian, was an inferior race.
Even before there were large numbers of
Negroes on our shores, the scar of racial
hatred had already disfigured colonial society.
From the sixteenth century forward, blood
flowed in battles over racial supremacy. We are
perhaps the only nation which tried as a matter
of national policy to wipe out it indigenous
population. Moreover, we elevated that tragic
experience into a noble crusade. Indeed, even
today we have not permitted ourselves to reject
or to feel remorse for this shameful episode. Our
literature, our films, our drama, our drama, our
folklore all exalt it. (King, 1963: 110)

That the representation of "Indians" does not reflect the First Peoples of North America represents a crucial paradigm shift even for First Peoples who are fighting to recover and restore a place in their traditional territories and within the human domain. Freedom from persecution, oppression, and marginalization requires redefining ourselves and taking our rightful place on lands where our spiritual connection is embedded. Redefining relationship based languages and ways of existing, not yet recorded in the consciousness settler populations, will restore that connection. Settlers cannot know the map or territory when they seek only to plunder riches, hence the plunder zone, 
with a greed that requires savage destruction of all levels of creation, including human. Our retelling of the story of Turtle Island for the coming seven generations is all our ancestors expect from us. The need to heal the scars of trauma from systematic alienation generated by the Indian Act is a battle of attrition for control of Canada. It is a battle that may or may not end our existence as a race:

Our Peoples have been denied both our dignity and humanity... Our Peoples in our relationships with the lands, waters and resources from which all life flows. The spirit of the land infuses our identity and life as Peoples. The distinctness of our lands and waters gave rise to the diversity of languages, cultures and laws of our Indigenous Nations. We are who we are as Indigenous Peoples because of our communities' adherence to our shared past and collective future. (Walkem and Bruce, 2003:347)

Ignorance and arrogance of societies that hold up such myths as empty lands or terra nullis as justification for colonization without full consciousness of the impact on the future legacies of their own peoples, let along the displaced, was what Korzybski sought to articulate. There were costs to all humanity, the settled territorial inhabitants in particular, but also to the mental wellness of those who have maintained delusionary rationales to cover their colossal errors against humanity.

The concept of "Indian" is not associated with ethnicity but has historically been a stage set in a social evolutionary ladder (Duran, 1995). It derived in part from the myth of the Wild Man and is directly oppositional to the equally ethnocentric concept of the Noble Savage. This limited identity was promoted by the first generation of anthropologists who were in effect socio/cultural missionaries competing for the privilege of anthropomorphizing those Savages. In the background was the relentless battle to occupy lands of a vast wilderness, thereby setting off a situation summarized by Benjamin Franklin in the 18th century by the following quote, "indeed if it be the design of Providence to extirpate these savages in order to make room for the cultivators of the earth, it seems not improbable that rum may be the appointed means. It has already annihilated all the tribes who formally inhabited the seacoast" (Duran 1995:125). That alcohol became part of the economy and a means of extracting concessions in dealing between two groups with conflicting values and intentions requires a great deal of examination especially in formulating healing strategies in First Nations communities today (Duran, 1995). An elder once describe how $100 \%$ of First Nations people are hurt by the misuse of alcohol. Eduardo Duran's book, Native American Postcolonial Psychology contains an important and significant review of the drunken Indian as a Eurocentric concept that fails to define the meaning of alcohol to First Nations people from a cultural, social, economic, political and historic point of view. He asks us to consider alcohol as having a spirit, which many of his First People clients describe. "Why do they call it a spirit"? He asks then responds,

When the patient is in search of spirit to
replace the spiritual and existential emptiness
caused by the soul wound, ego (the aspect of
the personality in which the personal identity
and experience is accessible) projects into the
spirit of alcohol. The spirit of alcohol then is
introjected by ego and consumed by the person
in its physical form ...In essence; the person is
replacing spirit with alcohol spirit in an attempt
to fill the void created by historic trauma
(Duran, 2006:65).

It creates a negative identity without helping a people to understand the illness, disease and social pathology of alcoholism. C.L. Higham (2000) provides a useful telling of the mutual dependency social scientists and government developed in civilizing Indians in North America. The most interesting story for Canada in this outline is the role of the Hudson's Bay Company in preventing the massacres of America in Canada for the sake of trade. Alcohol was a currency of that trade and much of the work of missionaries did was to lessen the damage from reckless usage of alcohol in order to create a spirit of cooperation. Canadian conquest of the frontier was profoundly different than the American approach (Higham, 2000). The common experience for First Peoples was brutal dislocation and an inability to recover from relentless onslaughts of migrations through Indigenous homelands. This again requires more study by First Peoples scholars to create a more reflective discourse for the social policies that brought Treaties, the Canadian Indian Act, Residential Schools, the Sixties Scoop, and the marginalization of Corrections Canada. Teaching the next generation of First Peoples social workers healing skills will require an inclusive socio-historical perspective that traces rampant pathology to these sad legacies.

The role of healer in a traditional or clinical role involves being a guide to piecing together shattered lives more resembling a scattered jigsaw puzzle. Through their influence I have gained training, professional role modeling, clinical experience and traditional teachings to help others reconfigure the pieces or stories of their experience. Traditional crafts and the practice of quilting can also create unique expressions that promote the sharing of stories and the transmission of core cultural values. There is a remarkable movie called the "How to Make an American Quilt (1995) by Jocelyn Moorhouse, starring Winona Ryder, Anne Bancroft and Maya Angelou. It tells stories within the framework of creating a quilt. The story does not present itself until all pieces are lovingly stitched together. The quilt is a metaphor for finding beauty in 
fragments or patches in cloth that comes together to create a lived story. In life these are the lessons of love, desire, betrayal, anger, heartbreak and forgiveness. This movie lets us follow a 26-year-old woman, Finn's (Winona Ryder), who is struggling with a life transition to that of an adult woman. Her access to the wisdom of older women in her life was for me a reminder of the horrific silence between First Peoples women and the failure to incorporate traditional values and life lessons in everyday living. In northwestern Ontario I initiated sewing groups for women to meet and share their stories with youth with a goal to creating healing quilts that would represent a lasting symbolism of their bonds. The ultimate goal was to restore the spirit of grass roots women to love, care, and share strengths in the face of an oppression that chokes the life spirit in most reserves. Culture like a quilt conveys an ethos or rubric that provides meaning, direction and coherence to its insiders. It is the collective utilization of natural and human resources to sustain our humanity. To that end it affects the way we feel, think and behave, (Berry et al. 1992).

First Nations author Lee Maracle teaches that trauma may best explored by artistic expressions such as poetry, theatre, painting, and story telling. The classic dimensions of isolation, hopelessness and victimization can be captured by words, (Amrani, 1993). A poem by Nila North Sun in Amrani (1993) highlights the contemporary First Peoples use of poetry as storytelling for expression of loss, anger, brutalization, alienation and prejudice:

$$
\begin{gathered}
\text { shadow is } \\
\text { my cousin } \\
\text { shadow was } \\
\text { my cousin } \\
\text { hated herself } \\
\text { because } \\
\text { others hated her } \\
\text { whites hated her } \\
\text { Indians hated her } \\
\text { called shadow } \\
\text { apple Indian } \\
\text { whites saw only INDIAN } \\
\text { fat drunk greasy squaw } \\
\text { shadow didn't know } \\
\text { what she was } \\
\text { my cousin killed herself } \\
\text { nothing new } \\
\text { we have lots of cousins } \\
\text { both dead \& alive } \\
\text { sometimes } \\
\text { both }
\end{gathered}
$$$$
\text { with the same shadow (pg.15). }
$$

Writing and story telling can allow for the expression of fragments of memory and recollections and evoke emotional expression. It allows a direct recounting of events long buried for the sake of self-preservation and mental health. Story telling is a long practice in First Peoples life ways, and ceremony and spiritual practices encourage community members to understand outside experiences as part of life that can bring suffering as well as goodness. This resonates for community helpers who incorporate an anti-ignorance and anti-arrogance approach to social work, or work with an anti-oppressive orientation to create healing environments. The goal is to allow participants the dignity to share fragments of painful experience and shed the isolation suffering places on the victims of trauma. Life is cyclical and different levels of experience require the honoring of relationships in physical, emotional, social and spiritual realms. Giving thanks for all gifts from creation means embodying a humility that accepts love, caring and sharing as the true marks of good living. Hatred, jealousy and greed as regarded as selfish, destructive and harmful to living well, and these emotions can hurt future generations. Ceremonies and cultural rituals orient First Peoples to a strengths based worldview. Unfortunately, the ignorance and arrogance of settlers confused the cultural relevance of Native adaptation to Euro-centric concepts with settler notions of racism, classism, sexism and the spiritual disunity they used to marginalize others through imposed inferiority.

Memory sharing through story telling means careful attention must be paid to moving healing narratives into, through, and beyond painful recollections so they are not merely released, but also form a foundation for relinquishing (Bear Heart, 1996) the damaging impacts of physical, psychological and sexual trauma (my emphasis). The blending of preventive life lessons to end abusive behaviors can bring ownership of harmful lifestyles that sometimes have a multigenerational foothold in families and communities. For instance, modern healing ceremonies are being tested and blended with traditional modalities out of a growing understanding of what residential school experiences represent for survivors, and how it changed their cultural orientations. As Elder Fred Wheatley in known to have stated, "We have to live in the world in which we find ourselves." In practice an invitation to share knowledge out of a linguistic interpretation can be an entry point to healing and change. In residential school healing circles in remote northwestern Ontario reserves participants were encouraged to find the words in their OjiCree language to denote the evil of harm to children. This linguistic exercise generally offered an important shift from painful silence to seeking a framework for story telling and memory recovery. These healing sessions were conducted over several days and the transition from fear and shame to support and empathy was a rewarding experience for 
all participants, including the facilitator. Collectively they were able to find a language of shared experience, wisdom and courage.

As an organizer of such sessions, the greatest reward came from being a witness to movement toward the restoration of a sense of connection in family, community and even nation. Participants became aware that rather than being ashamed about the loss of collective language or cultural identity, because they each carried fragments of wisdom and traditional knowledge; they could prompt their healing as a group. Another group exercise was done to assist parents in approaching their children to express their hidden pain in perceived failures in parenting and to formulate new loving attachments. They needed to let go of their need for fierce control over the possible disclosure their own youthful exuberance and subsequent mistakes that had not been given voice. They were asked to place their hands on their heads and state "I did not know" then place their hands on their hearts and exclaim, "I am so sorry". These acts of personal and psychological liberation have become a part of a truth and reconciliation process that this author continuously strives to facilitate.

Geertz (2000) states that, "psychology's next generation will help resolve these deep on-going issues by highlighting narrative as a primary way of knowing our reality" (p. 193). He directs us to the work of Jerome Bruner, who he calls one of the leaders of the Cognitive Revolution. Bruner has noted that it is the analyst who facilitates the constructional process of the telling of self-stories. The self derives from individual meanings and cultural participation. "The human mind and lives are reflections of culture and history" as well as biology (Geertz 2000, p.198). For Bruner "narratives" show how experience is organized and becomes sequential, following sets of events, mental states, and other responses. Therapy often entails the huge task of safely taking someone through life sequences, which have been interrupted by intrusive painful memories. Jerome Bruner's writings on cultural psychology offer endorsement for First Nations social change activists using cultural narratives. These stories offer a reality testing revision of conventional or colonial based understandings of what is wrong in our communities. Bruner calls culture "the way of life and thought that we construct, negotiate, institutionalize, and finally (after it is all settled) end up calling 'reality' to comfort ourselves" (Geertz 2000, p. 192). A story or narrative that Marlene Brant-Castellano (1987) uses to frame cultural teachings represents another important way of knowing:

If you're out on the lake in a canoe and a sudden storm blows up and your canoe tips over, you will have a stress reaction. You will have a surge of energy and you can do any of three things. You can give up and sink like a stone. You can get angry and thrash about, at which point you will get exhausted and drown or you can channel your energy, you can hang onto your canoe and wait for the storm to pass and then deliberately upright it and get back in. But how do you know not to panic? How do you know that you don't fight the storm and how do you know to get your canoe upright? How does any body learn these things for survival? What, I believe very firmly, what we as Native people need to do is to actively search out those teachings which instruct us in how to wait out the storm, if that's the survival way to go. The technology of how to handle a canoe and read the weather so we don't get into a storm in the first place and how to discipline ourselves in order that we choose the creative solution and not the one that destroys those around us (p.87).

This is a profound message that could be a real key turner in workshops for violent men, for allies in stopping FASD, and to create prevention strategies for suicide and addictions. The loss of teachers, elders, positive youthful role models and mentors of all ages for First Peoples youth leads to our losing them to gangs, violence, incarceration and substance abuse. Mate (2007) in writing about addictions states;

\begin{abstract}
Neglect and abuse during early life may cause bonding systems to develop abnormally and compromise capacity for rewarding interpersonal relationships and commitment to social and cultural values later in life. Other means of stimulating reward pathways in the brain, such as drugs, sex, aggression, and intimidating others, could become relatively more attractive and less constrained by concern about violating trusting relationships. The ability to modify behavior based on negative experiences may be impaired (p.197).
\end{abstract}

We must engage in family and community reality checks that offer insights beyond basic survival to understanding how our children are leaving their family and community of origin. The decline in our youth and family well-being shows its painful face in incredible loses to suicide and early death through recklessness, self-destructive and self-defeating behaviors. In many instances, communities in the north in particular, have little support to recover and restore hope. Together with a failure to provide young people with strength-based cultural wisdom and preparation for assuming prominent roles, are the obvious markers of dis-ease and early death in our nations (Wesley-Esquimaux, 2009). We need to create a narrative path focused seven generations ahead to mitigate the historical damage of our 19th and 20th century experience. In the 21 st century we face the very prospect that issues like suicide, sexual violence and increasing numbers of FASD/ARND incarcerated youth will continue to impair our journey forward. We need to look everywhere 


\section{Metaphorical Reflections on the Colonial Circus of the Drunken Indian and the Kidney Machine}

for indicators of extinction, especially in our Indigenous homelands in remote Canada. There we are impacted by mining interests, forestry interests, and a chronic lack of societal care.

If we fail to move beyond what has manifested over time as a genocidal dependency on the colonizers and their cash, we will become footnotes of history like the Beotuks and Petun tribes that fell to the 17th and 18th century ravages of Turtle Island. For all of our peoples this was only one period of cultural devastation in the name of progress, we are fighting the same battle today in our northern hemispheres. We must teach our youth that they are the "last best hope" for all Indigenous people globally. The ultimate survival of Canada's First Peoples will be proof that genocide through the neglect of basic human rights to health care, economic sustainability, and educational facilities is not an acceptable tool for the continuing domination of mythical "empty lands" and the misrepresented peoples who live upon them. The myths around nationhood on Turtle Island are clearly up for debate and new alliances must be made possible to formulate a just and equitable society. The truth and reconciliation process still being contemplated but at this time problematic in design by Canada, though discomforting to its government and Churches will give young First Peoples real stories to organize their experience through and will hopefully provide an invitation to recover, relinquish historic trauma, and restore traditional life-ways.

Lee Maracle (2009) teaches that successive generations have been obstructed in their ability to help their children navigate and negotiate racism, classism, sexism and colonization in their "coming of age" life journey. She lectures on the failure of adults through their absence being unable to teach autonomy and adaptation skills for youth struggling to gain authority in their life path. Adults are to assist in clearing a path of mastery by moving strengthened minds and bodies towards good will and Biimaadiziwin for successful life paths. Maracle (2009) calls the lifespan ages 13 to 20 the "Days of Decision" where young people navigate and negotiate how 'all my relations' will play out in their own lives as guideposts to ecological reciprocity. Their sense of connection is a vital part of the resilience they need to pass through periods of uncertainty and confusion. Chaotic rhythms in their homes and alienation of their homelands lead to feelings of despair, helplessness, hopelessness and ultimately to an identity crisis that make living seem impossible. The excesses of violence, substance abuse and suicide must be examined from the context of the youth watching and deciding. We must also consider the implications of neurological damage from FASD that compound an increasingly urgent need to stop damages and instead maximize human potential within our growing youth population. By the age of 25 when society expects young people to be fully functioning and contributing to society, our youth remain in what elders call the Wandering Stage of life (Maracle, 2009). Instead of contributing, they follow a self-centered path of uncertainty, not knowing their place in the world, which in turn leads to selfishness, recklessness and carelessness.

Marlene Brant-Castellano's (1987) story-telling paradigm may offer clues to how these panic causing life storms can also create pathways of knowing and crucial growth opportunities, because the failure to formulate positive life-paths for young Native peoples will only continue to contribute to chaos and uncertainty. Not taking charge of these teaching opportunities threatens our cultural competence and cultural survival. Think of the narratives of possibilities that could be used to triumph over adversity, and that could direct and move youth beyond despair or mere survival.

The sharing of trauma experiences by residential school survivors who [as children] experienced and witnessed pain without being able to tell anyone is deeply moving. We have to honor the journey of self-discovery undertaken by victims longing for peace from their incomprehensible suffering. Their suffering in silence comes from not hearing resilience stories from adults in the healing ceremonies of their communities. Selekman (2002) addressed storytelling for First Peoples as a healing principle:

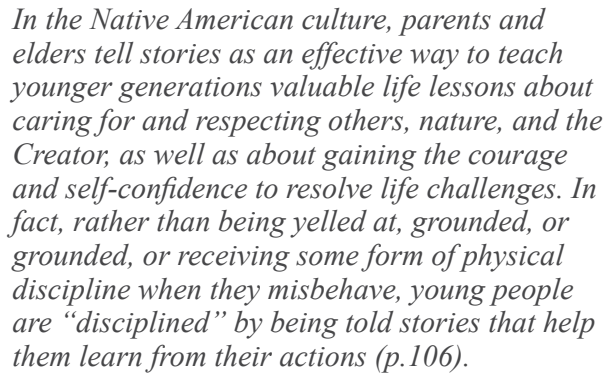

Selekman (2002) speaks to self-harm and cutting behaviors in adolescents, one of the most serious risk behaviors in First Peoples communities, and youth. The cutting is reflective of the inner turmoil they keep to themselves and inflict onto their physical self. Alice Miller's (1990) book For Your Own Good: Hidden cruelty in child rearing and the roots of violence also contains an excellent review on how violence and cruel manipulation of children can create violent adults. There is also a valuable lesson for pedagogy in the legacy of untenable methods used in residential schools for "civilizing young savages". A story narrative, possibly also a science lesson, from the Fort Albany residential school is recounted in Joseph Boyden's (2005) novel Three Day Road:

The old Cree are heathen and anger God [the nun says] The Cree are a backwards people and God's displeasure is shown in that He makes your rivers run backwards, to the north instead of to the south like in the civilized world... 
When you accept Him He will perform a great miracle. He will cause the rivers in this barren place to run in the right direction (p.52).

Bruner suggests our place in the world flows from metacognition or "how we think about our thinking" (Geertz 2000: 194). As described by Bruner, "history, culture, the body and the workings of the physical world, indeed fix the character of anyone's mental life, shape it, stabilize it, fill it with content but do so independently, concurrently, and differentially. He adds, "the way of life and thought that we construct, negotiate, institutionalize, and finally (after it is all settled) end up calling reality to comfort ourselves" (Geertz 2000: p. 192). I am drawn to the implications of this theory on my future work; especially my desire to be part of crucial preparations and closures for truth and reconciliation sharing circles that are an important feature of the Indian Residential Schools Compensation Package. The next 5 to 10 years will hopefully clarify many outstanding misunderstandings and misconceptions about the historical realities of Canada and the First Peoples who live 'here.'

The voicing of alternative perspectives for healing paradigms that respect Indigenous Knowledge may shine understanding on why mainstream mental health helping strategies have largely failed to assist in the restoration of the good life in our communities. The mislabeling of reactions to racism, classism, sexism, colonization and oppression as pathology have only entrenched stigma and stereotype. Interference in the natural evolution of the language and behavior of adaptation is rarely mentioned as an area of contention when considering how First Peoples have managed their own historical realities. Reestablishing community healing mechanisms, such as the sharing of narratives for exploring trauma from residential school memories, and naming the personal "dis-eases" generated from intensive human suffering and pain, will help to expose internalized negative beliefs. Self-reflection is critical to the restoration of Indigenous resilience. There are collective stories of multiple losses, beginning with the loss of connection to a family at birth, whether through FASD neurological damage or disproportionate foster care apprehensions, needing a complete reorientation of the sad cultural inheritance of seven prior generations. Much of this knowledge would be lost in a "systemantic" (Gall, 1975) attack on Indigenous community and has already undermined their core values of love, caring and sharing. It is necessary to remind all social workers that what constitutes "best practices" in the history of social regulation and the maintenance of the civilization we are asked to maintain and endorse as "civilized" is not necessarily coherent with First Peoples practices and worldviews. Does their alibis for remediation sustain state sponsored oppression, repression and dispossession?
Indigenous healers have always utilized "wise practices" (Thoms, 2007), which were based on harmony, balance and good will; they returned to and incorporated the inner spiritual and inner knowledge of place and spirit. The legacy of the unrelenting attacks and marginalization of traditional healers is ever present on the ground. Healers are faced with a continuity of suffering and despair from violence, sexually predatory behaviors, alcoholism and early death by self-destructive and self-defeating behaviors. Much of this behavior has become normalized to the point of creating deafening silence in the face of tragedies such as Yellow Quill, youth suicide or the loss of hope in our young in far too many places across this land. People are speaking out in various places, but are they being heard in the places that matter? The intense pain of earlier generations who were subjected to being deprived of a childhood still reverberates in First Nations communities in Canada, and is revisiting the world in areas where childhood is being destroyed by warfare, child prostitution, famine and disease. The restoration and recognition of "wise practices" offers the best hope for finding a way forward from the despair and hopelessness that permeates families and communities. We can no longer be dependent on a dominant culture interpretation of what it means to be successful and fully living First Peoples. Indigenous scholars must uncover the direct influences of Indigenous wisdom on the collective consciousness of the past seven generations, especially the 20 th and 21 st century of psychological and cultural impact.

In 1938 Abraham Maslow under the direction of Ruth Benedict conducted six weeks of fieldwork on the Blood reserve in Alberta. Maslow (1979) would affirm the value of Blackfoot worldview contributions to his psychology theories human behavior and human social organization, which began to evolve from lessons from the Blackfoot tribe. He witnessed the on the ground impacts of white racism which troubled him that confirmed destructive state policies that resulted in stolen lands, stolen children and collective marginalization. By 1967, only one generation away from his 1938 visit Maslow hears from A.D. Fisher, a graduate student he is supervising that addiction and violence were fast becoming the new social norms of the Blood community. Fisher (1984) calls for explanations of "how and why the outcome of "reservationization" turned out to be Indian underdevelopment in "the bountiful land of Alberta". There are Indigenous thinkers such as Ryan Heavy Head (2009) researching this little known story from Red Crow Community College.

Lee Maracle (2009) offers an interesting refection on Abraham Maslow's (1954) needs-based theory on human development and the motivating factors for a good life. She suggests for First Peoples, Maslow's hierarchy is an upside down pyramid. Maslow's idea of the triangle may have come from tipi teachings Maslow received in 1938 (Hanks, 


\section{Metaphorical Reflections on the Colonial Circus of the Drunken Indian and the Kidney Machine}

1950). This is an interesting example of a difference in worldviews that can shift psychological wellness concepts that Western thinkers promote as basic best practices to Indigenous Spiritual knowledge which is tied to creation and being of a good mind. If all life is spiritual first, then as Lee Maracle states, self-actualization is not the peak experiential calling for achieving a good life, it is the beginning. Traditionally, First Peoples viewed children as complete gifts from creation with their potential intact when they arrived, and that all members of a community simply prepared for communal membership. They are already filled; therefore, basic needs as Maslow describes them, are in fact, the last level of cultural competence for successful mastery of a good life. First Peoples know that kindness and sharing will naturally arise from achieving ones full potential. This inverted pyramid of a full spiritual life is little appreciated by so called "social helpers" who focus on what they perceive as poor living conditions. This visual becomes the tangible expression of poverty and pathology, rather than the result of a coercive removal plan named greed for the lands and resources of an entire population. Children are removed and First Peoples are punished to meet Maslow's basic needs for a selfish, indifferent and thoughtless dominant culture with no understanding of the spiritual connection to the future generations of Native peoples, or respect for the limits of their mother earth.

Compare this work to that of other modern ideas emulating from Albertan intellectuals especially from disciples of Tom Flanagan who question the validity of Indigenous knowledge and worldviews or claims to inherent human rights beyond what Canada is prepared to offer. He praises their questionable scholarly material that in context and content borders on racism and promotes rationalizations for continued white supremacy. Frances Widdowson and Albert Howard (2009) in their disturbing and misguided book "Disrobing the Aboriginal Industry: The Deception Behind Indigenous Cultural Preservation", raise valid issues on the growing industry of nonAboriginal consultants profiting from First Nations misery, but denigrate Indigenous peoples throughout. Widdowson and Howard (2009) in a true social-Darwinism framework postulate, "to some extent the dislocation that [(a)boriginal] peoples are feeling is inevitable since it is difficult to bridge such a large development gap in a few hundred years" (pg. 259). On the same page in a cotton candy/candy apple moment they quote from John Lennon's quaint song, "Imagine", "I hope some day you'll join us, And the world will live as one". Our history lessons are painfully distinct from their wonder bread world and I invite Widdowson and Howard to instead meditate on Buffy Sainte Marie's superior anthem "The Big Ones Get Away". Every Indigenous change agent recognizes Buffy Sainte Marie's dedication to revolutionary change. Her lyrics from that song; "Money junkies hire all the smart ones" and "If the bad guys don't get you Baby, then the good guys will", are far more informative to Indigenous people then any words writers such as Flanagan, Widdowson and Howard, and anything they could ever string together in their quest to legitimize a world dominated by white privilege. WesleyEsquimaux (2009) in a recent review of Widdowson's book writes that the book highlights a disturbing trend on what is becoming acceptable academic literature where a litany of "hatred and conjecture [is allowed to] re-enter the doors of tolerance and respect". Gerald Taiaiake Alfred (2009) in a 'wise guy' style also reviews this author and titles his commentary "Redressing Racist Academics, Or, Put your Clothes Back On, Please!" He addresses the intellectual inadequacy, hatred and contempt that has permeated Canadian media (especially misinformed, ignorant and arrogant writers such as the National Post's Jonathan Kay (2009), and the Globe's Margaret Wente) as inexcusable in academia. Hey, Jonathan getting rid of Third World conditions in First Nations requires rational dialogues on land and resource sharing and concepts like homelands as opposed to refugee camps (reserves) (01/16/09). A fairer analysis on the inequities of the Canadian state is provided by "A Fair Country: Telling Truths About Canada" by John Ralston Saul (2009). This author (Koptie), on reading Colin Tatz's 2003 book titled, "With Intent to Destroy: Reflecting on Genocide", would suggest it to wasting valuable intellectual time reading those colonial clowns, Flanagan, Widdowson and Howard, Kay and Wente. All Indigenous scholars need to offer rigorous challenges to the tired ideology coming out of Alberta, a major part of the new frontier of resource plunder and anti-Indigenous politics and policies for which Flanagan, Widdowson and Howard run the alibis.

Aloss of obligation seven generations forward generated massive damage to the overall well being of our planet. The First Peoples plight has become a global experience where human populations are extinguishable in the name of wealth, just as the land, water and air that sustains them can be destroyed. The "capitalistic minority" of the planet profit from stealing wealth from "plunder zones" around the globe, from lands, which are generally occupied by Indigenous peoples. The real story of drunkenness is the inebriation of greed and hatred we find within the neverending party of consumerism and acquisition (Maracle, 2009). The spiritual disconnect from interdependency that has infected humanity is poorly studied, and hidden under convenient language that quickly dismisses any impact on people, place and spirit. First Peoples must sustain a framework of Indigenous Knowledge that can bring back our sense of time and place. These teachings lay dormant in the narratives that once revived, will inspire us seven generations into the future. It is our role as Indigenous people to offer alternative perspectives on survival that will create new pathways from those taken for the past 
500 years that have caused misery to most of the people on earth. If we were to turn the basic need pyramid upside down for ourselves, we would recognize the self-actualized existence the Creator has already provided for us. We would take only what we need out of a sense of graciousness, caring and sharing in order to not adversely impact those from whom we borrow our time and use of the land. We own nothing but a series of life sustaining relationships with all our relations. The Haudensaunee Thanksgiving Prayer is the most coherent spiritual directive, calling for a good mind and good life. To hear Mohawk Elder Tom Porter recite this code of conduct for all humanity reminds us that we are truly all one creation.

Geertz (2000) tells us that Thomas Kuhn has a wall hanging with the saying "God Save This Paradigm", as a reminder of the need to challenge the entrenched notions of the cultural superiority of Western civilizations from the past several centuries. Kuhn called for "socio-historical science studies" to resist the trends of "subjective, irrational, and mob psychology" (p.166). He observes the tendency of historians, economists, anthropologists, science writers as well as philosophers, and the fields of religion, art, literature, law, and political thought to alternate between long periods of "normal" stability and short bursts of revolutionary upheaval. The past century gave us feminism, the end of modernity, New Age mysticism, the decline of Western hegemony and skepticism of rapid technological change (Geertz, 2000: 165). These events were foreshadowed in Kuhn's writing in the 1950-60's, and provide a way of viewing upheaval by shifting our consciousness to reevaluate the socio-historical roots of oppression and domination. Kuhn's also comments on how day-to-day experiences impact our sense of the acculturation process and adaptation to a sometimes unfriendly and unsafe dominant culture, as well as the resistance, resentment and rebellion associated with being "the other."

The American novelist, playwright, and essayist, James Baldwin (1955), tells a story, "Stranger in the Village" that triggered a personal identity crisis. When he visited a small Swiss village just after World War Two, children unaccustomed to seeing an African-American man found him "a sight" and called out "Neger, Neger" (p.1). He states he was "far too shocked to have any real reaction" other than the awkward smile one learns in the presence of ignorance and arrogance when a return sensitivity lesson is impractical (p. 1). His essay is a remarkable example of cultural relativism and how culturally derived categories can evolve into folklore, here the curse word Nigger. Baldwin (1955), traces this imposed identification to the tragic socio-historical remnants of slavery suggesting; "the history of the American Negro is unique also in this, that the question of his humanity, and his rights therefore as a human being, became a burning one for several generations of American, so burning a question that ultimately became one of those used to divide the Nation" (p. 4). Baldwin argues that Americans created this abstraction, which then became a spectacle to support their heritage of "white supremacy". White supremacy according to Baldwin rests on the myth that "white men are the creators of civilization; the only one that matters, (all previous civilizations are simply contributions) and therefore they are civilization's guardian and defender" (p. 5). This essay written in 1955 could be an editorial today and it ends with a prophetic statement regarding the "foolish and dreadful" denial of history in America, "the world is white no longer and it will never be white again" (Baldwin,1955: p. 6). Barak Obama ascension to the 'White House' in 2009 begins a new narrative for future generations of mislabeled humanity.

Clifford Geertz's essay, "The Uses of Diversity, A Reflection on Ethnocentrism" has a reference to the Levi Strauss' (1985) concept of "relative uncommunicability". This concept was used to describe the dangers of ethnocentrism being "partially or totally insensitive to other values" and not recognizing that other cultures carry traditional values that maintain their place in the world they identify as their culture space. Ethnocentrism is not presented as an illusion that all humans would live in a world "whose cultures were all passionately fond of one another, in such confusion that each would lose any attraction it could have for the others and its own reason for existing" (Geertz 2000: p. 70). Warfare, economic upheavals, loss of empire and more recently environmental decline cause us to cling to core values to help us cope with the "state of the world" as we experience it and these realities. If we live in a collage, as Geertz (2000), suggests, or a quilt as Moorhouse suggests, we must arrange the elements of what is vital to us to come to a sense of agreement and commitment that can lead us to peace, harmony and commonality. He calls for "the moving away from to-eachhis- own indifferentism, dismissing it is as charming, lovely even as [Pow-Wows], but inconsequential"' (p. 87). As we look to the 21 st century we are confronted with historic legacies of chronic misunderstanding and the rampant ethnocentrism of the 19th and 20th centuries. Diversity is a fact in contemporary times, and deciding if it is to in fact lessen cultural distance or remain a source of conflict becomes our modern challenge (Berry et al., 2003).

The moral issues of ethnocentrism in narrative form are found in "The Case of the Drunken Indian and the Kidney Machine" (Geertz, 2000: pp. 79-80). I found this story an excellent representation of the profound moral issues around alcohol and drinking patterns in First Nations populations. I have many personal experiences of discrimination, humiliation and shame around alcohol. My ex-wife's mother initially rejected our relationship because "Indian men drink and beat their women" and in my first job interview out of university in 1980 I was asked if "I was an Indian and if I drank?" In 1984 I was employed 
with the Catholic Children's Aid Society of Metropolitan Toronto as a First Nations child welfare worker. I was asked in the lunchroom one day, "Why do Indians drink?" My reaction was somewhat belligerent, "Wait a minute, you mean you have a Masters of Social Work in Canada and do not know why Indians drink?" I was the one called into the manager's office for being insensitive. I never had lunch in that building again because it came to be a constant reminder of being an outsider in a culturally unsafe working environment.

I offer these stories of discrimination against Native man in a dominant white culture as a lead to "The Case of the Drunken Indian and the Kidney Machine". It is a story from an anthropologist from the southwestern United States who presented it as a representation of the huge cultural gap between medical staff and the Indian patients that presented for treatment at a local tribal health clinic. In a time of scarce health care resources, long waiting lists and costs, the staff at a medical clinic are shocked by an Indian man, who after gaining access to a kidney dialysis machine refused to stop drinking or control his drinking; he sees the treatments, which he never missed, as helping him live longer. His position was that yes, he had been a "drunken Indian" for some time and he intended to keep drinking as long as they could keep him alive. The conflicting moral issue for medical personnel around someone taking a healing treatment spot from others without the prospect of improvement in their quality of life was perplexing. He did die of complications from alcohol abuse. His story is more a representation the Spirit of Alcohol (Duran, 1995) and the sad relationship developed historically with alcohol that eventually took on a life of its own. The chronic lack of treatment, prevention programming, and harm reduction services in First Nations communities do not allow strong intervention in a cycle that has become intergenerational. I have an expression for those who refuse to help someone because they blame the victim for their inability to make choices or changes to their circumstances, "You are punishing him/her for living like an Indian." The normalization of dangerous drinking patterns such as binge drinking and other substance abuse problems to cope with life stresses in First Nations populations has become an historic legacy that seems to belie change and healing. Therefore this expression, albeit awful and racist, holds its own sad truths.

I return to our dilemma of adapting to modern times. We are ultimately left swinging between the ignorance and arrogance of the dominant culture, and our inability to create deep sustainable change at the ground level of our communities. We are waiting for history and the government to solve the hatred, jealousy, and greed of the past 500 years and alleviate our suffering. The metaphor or icon of the drunken Indian opens many avenues for further research. For me, understanding the role of alcohol in colonization is helped by a circus metaphor. Colonized people are the performers in this circus and social scientists represent P.T. Barnum, who is looking for the next oddity to draw a crowd, and to entertain the dominant culture (audience). Nothing draws a crowd better than a "drunken Indian" with all the inherent subjectivism, nihilism and incoherence. This is where this paper ends as a call for a fulsome restoration of the stories of Indigenous people around the world in the language of their ancestors and in a sequence that recovers those values that allowed members the dignity of recovery from pain and suffering. Stopping the dramatic performances of alcoholism, FASD/ ARND, youth suicide, family violence and alcohol abuse requires ownership of a vast socio-historical truth that can also provide a context from which to design a national identity that is not a predatory side show. The First Peoples of Canada must lead the movement to reconciliation and restoration of a positive identity. Those who think violent confrontation is needed to put others in their place will only extract useless revenge and become the clowns in the colonization circus. Being raised on a traveling carnival and understanding the use of diversions to gain and sustain advantage I also know that you cannot perpetually fool everybody. The next 50 years and the future of Canada may well prove to be the "Greatest Show on Earth".

\section{References}

Alfred, T. (2009). Review of "Disrobing the Aboriginal Industry". Posted January 16, 2009 http://www.taiaiake.com.

Amrani, N. (1993). American Indian Women Poets: Women between the World. New York, NY: Vantage Press.

Armitage, A. (1995). Comparing the Policy of Aboriginal Assimilation, Australia, Canada, and New Zealand. Vancouver, BC: UBC Press.

Baldwin, J. (1955). "Stranger in the Village" from Notes of a Native Son. Boston, MA: Beacon Press: Retrieved from http://www.uwm.edu/ gjay/Whiteness/stranger.htm.

Bear Heart, and M. Larkin (1996). The Wind Is My Mother: The Life and Teachings of a Native American Shaman. New York, NY: Berkley Books.

Berry, J., Mishra, R., and Tripathi, R., (2003). Psychology in Human and Social Development: Lessons from Diverse Cultures. Thousand Oaks, CA: Sage Books.

Blatchford, C. (2009). "It's no accident that what happens at Yellow Quill ... happens." Globe and Mail, 23/02/08, Toronto, ON.

Boyden, B. (2005). Three Day Road. Toronto, ON: Viking Canada.

Brant-Castellano, M. (1987). Family Violence A Native Perspective. In Canadian Psychiatric Association, Section on Native Mental Health, Transcribed and Edited Proceedings of 1987 meeting, London. ON.

Chun, K.M. P.B. Organista and G. Marin (2003). Acculturation, advances in theory, measurement, and applied research. 


\section{First Peoples Child \& Family Review, Volume 4, Number 1, 2008}

Washington, DC: American Psychological Association.

Deer, T., (2005). Mohawk Girls (DVD), Revolution Pictures International and the National Film Board of Canada.

Duran, E. (2006). Healing the Soul Wound. New York, NY: Teachers College Press Columbia University.

Duran, E., and Duran, B., (1995). Native American Postcolonial Psychology. Albany, NY: State University Press.

Ellis, A. (1975). how to live with a neurotic. Hollywood, CA: Wilshire Book Company.

Gall, J., (1986). Systemantics, The Underground Text of Systems Lore, How Systems Really Work and How They Fail. Ann Arbor, MI: The General Systemantics Press.

Gall, J. (1975). Systemantics, How Systems Work and Especially How They Fail. New York, NY: Pocket Books.

Geertz, C. (2000). Imbalancing act: Jerome Bruner's cultural psychology. In Available Light (pp.187-202). Princeton, NJ: Princeton University Press.

Gore, A. (2006) Inconvenient Truths: A Global Warning (DVD), Paramount Pictures.

Hanks, J., (1996-1997). Lucian and Jane Hanks fonds: M 8458, M 8078, M4387. Glenbow Museum, Cargary. Retrieved from http://www.glenbow.org/collections/findingAids/archtm/ hanks.cfm.

Hanks, L., and Hanks, J. (1950). Tribe Under Trust: A Study of the Blackfoot Reserve of Alberta. Toronto, ON: University of Toronto Press.

Hercz, R. (2007). The Rat Trap, Why Canada's drug policy won't check addiction. Toronto ON: The Walrus, December 2007 Volume 4 Issue 10.

Higham, C. (2000). Noble, Wretched, and Redeemable, Protestant Missionaries to the Indians in Canada and the United States, 1820-1900. Albuquerque, NM: University of New Mexico Press.

Hoffman, E. (1988). The Right to be Human: A Biography of Abraham Maslow. New York, NY: Jeremy P. Tarcher, Inc.

Kay, J. (2009). Yellow Quill, and the folly of aboriginal "sentencing circles". Posted January 16, 2009, Toronto, ON: National Post.

King, M. (1963). Why We Can't Wait. New York NY: Signet Classics.

Korzybski, A. (1933). Science and Sanity. Garden City, NJ: Country Life Press.

Maracle, L., (2009). Lectures, Aboriginal Non-Fiction Writing. University of Toronto.
Maslow, A. (1979). The Journals of A.H. Maslow, Volumes 1 and 2. California: Brooks /Cole Publishing.

Miller, A. (1990). For your own good, hidden cruelty in childrearing and the roots of violence. New York, NY: The Noonday Press.

Moorhouse, J. (1995). How to Make an American Quilt, Universal Pictures USA.

Power, S. (2002). A Problem from Hell, America and the Age of Genocide. New York, NY: Harper Perennial.

Rapp, C. (1998). The Strengths Model: Case Management with People Suffering from Severe and Persistent Mental Illness. New York, NY: Oxford University Press.

Sainte Marie, B., (1996). The Big Ones Get Away. Retrieved from http://www.slyrics.com/songs/s/saintemariebuffy $5336 /$ thebigonesgetaway223223. Saul, J. (2009). A Fair Country: Telling Truths About Canada. Toronto, ON: Viking Canada.

Selekman, M. (2002). Living on the razor's edge, solutionoriented brief family therapy with self-harming adolescents. New York, NY: W. W. Norton \& Company.

Smith, L. (2006). Decolonizing Methodologies: Research And Indigenous Peoples. New York, NY: Zed Books.

Tatz, C. (2003). With intent to destroy: reflecting on genocide. Verso: London, UK.

Thoms, J. (2007). Leading an Extraordinary Life: Wise Practices for an HIV prevention campaign with Two Spirited men. Toronto, ON: 2-Spirited People of The 1st Nations.

Trudell, John (2004). Trudell: The Movie, Big Buck Releasing, USA.

Walkem, A. and Bruce, H. (2003). Box of Treasures or Empty Box? Penticton, BC: Theytus Books.

Wesley-Esquimaux, C. and M. Smolewski, (2004). Historic Trauma and Aboriginal Healing. Ottawa, ON: Aboriginal Healing Foundation Research Series.

Wesley-Esquimaux, C., (2009). Lectures on Aboriginal Mental Health, Introduction to Aboriginal Studies, University of Toronto, Toronto, ON.

Widdowson, F. and Howard, A. (2009). Disrobing the Aboriginal Industry: The Deception Behind Indigenous Cultural Preservation. Montreal, QC: McGill-Queens University Press.

Yellowhorse-Braveheart, M, and DeBruyn, L. (1996). The American Holocaust: Healing Historical Unresolved Grief. Unpublished paper, Retrieved from http://www.class.uidaho. edu/engl504trauma/Braveheart.pdf. 